\title{
Intestinal nonrotation and left-sided perforated appendicitis
}

\author{
Ertan Zengin, M.D., ${ }^{1}$ Arzu Turan, M.D., ${ }^{1}$ Ahmet Salih Calapoğlu, M.D., ${ }^{3}$ \\ Ercan Nalbant, M.D., ${ }^{2}$ Gürkan Altuntaş, M.D. ${ }^{2}$ \\ 1Department of Radiology, Recep Tayyip Erdoğan University Faculty of Medicine, Rize-Turkey
Department of Emergency Medicine, Recep Tayyip Erdoğan University Faculty of Medicine, Rize-Turkey
${ }^{3}$ Department of Pediatric Surgery, Recep Tayyip Erdoğan University Faculty of Medicine, Rize-Turkey
}

ABSTRACT

Acute appendicitis is the most common cause of acute abdominal pain, requiring emergency surgery. Approximately one third of cases have pain unexcepted location due to its various anatomical location. Acute appendicitis is a very rare cause of left lower quadrant pain; if it occurs, a few congenital anomalies should be considered such as Situs Inversus totalis and Midgut Malrotation (MM). MM is a rare congenital anomaly; it occurs due to error in process of rotation or fixation of intestines around the superior mesenteric vessels and it refers to nonrotation or incomplete rotation of intestines. Here we report a case who presented with left lower abdominal pain and was diagnosed with acute perforated appendicitis with intestinal nonrotation. Clinicians should be aware that intestinal nonrotation may be presented with left lower quadrant pain and complicated by acute appendicitis.

Keywords: Acute appendicitis; intestinal nonrotation; left lower abdominal pain; midgut malrotation.

\section{INTRODUCTION}

When the intestines move outside the abdominal cavity during the development of a fetus, it is called a physiological umbilical hernia. In about the $10^{\text {th }}$ week of the prenatal period, once the abdomen enlarges, the small intestines can reenter the abdominal cavity after completing a complex developmental process outside the abdomen. Due to the complexity of this process, a number of digestive tract abnormalities can occur, such as midgut malrotation (MM), as a result of the rotation of the midgut loop. It is very important for radiologists and surgeons to be aware of the anatomical location of the intestines.

\section{CASE REPORT}

A 13-year-old male patient was admitted to the emergency department of our hospital with acute abdominal pain and vomiting. He had no significant medical history, except for abdominal pain that started 3 days previously. Patient explained that initially the pain began in the paraumblical area and later expanded through the left lower quadrant. Physical examination revealed left lower quadrant rebound tenderness with guarding. Routine vital signs of the patient (blood pressure, body temperature, and the pulse rate) were normal. Laboratory tests revealed leukocytosis $\left(12.31 \times 10^{3} /\right.$ UL), with $88 \%$ neutrophils, and C-reactive Protein was elevated $(6.31 \mathrm{mg} / \mathrm{dl})$. Other laboratory tests including blood sugar, electrolyte, and liver and kidney functions were normal. Because of the persistence of pain and rebound tenderness, abdominal ultrasonography (USG) examination was performed first. Abdominal USG showed dilated blind non-peristaltic intestinal loop, with fecalith on left lower quadrant, and minimal free fluid in the abdominal cavity. The liver and spleen were in their normal anatomical locations. These findings were consistent with acute appendicitis in left lower quadrant. Contrast-Enhanced Computed Tomogra-

Cite this article as: Zengin E, Turan A, Çapaloglu AS, Nalbant E, Altuntaş G. Intestinal nonrotation and left-sided perforated appendicitis.

Ulus Travma Acil Cerrahi Derg 2018;24:178-180

Address for correspondence: Arzu Turan, M.D.

Recep Tayyip Erdoğan Üniversitesi Tıp Fakültesi, Radyoloji Anabilim Dalı, Rize, Turkey

Tel: +90 464 - 2123009 E-mail: rztrn72@gmail.com

Ulus Travma Acil Cerrahi Derg 2018;24(2):178-180 DOI: 10.5505/tjtes.2017.58726 Submitted: 09.10.2017 Accepted: 10.11.2017 Online: I2.02.2018

Copyright 2018 Turkish Association of Trauma and Emergency Surgery 
phy (CECT) was performed for preoperative management and to confirm the diagnosis. CT revealed that small bowel was on the right half of the abdomen and large bowel was on the left half of the abdomen. Considering these findings, secondary left-sided acute appendicitis (LSAA) is contemplated in MM (Fig. I). In addition, left kidney was malrotated. Superior mesenteric vein (SMV) was on the left side of the superior mesenteric artery (SMA) (Fig. 2a). Moreover, type Ia hepatic vein and right portal vein variation as well as polysplenia were observed (Fig. 2b). Coronal reformatted CT images showed markedly dilated appendix $(2 \mathrm{~cm})$ and fecalith $(2 \mathrm{~cm})$. There were a few enlarged lymph nodes in the mesentery (Fig. 2c), and free air and focal mesenteric stranding were around the proximal part of appendix on axial CT images (Fig. 2d). Based on these findings, left sided acute perforated appendicitis was diagnosed and emergent

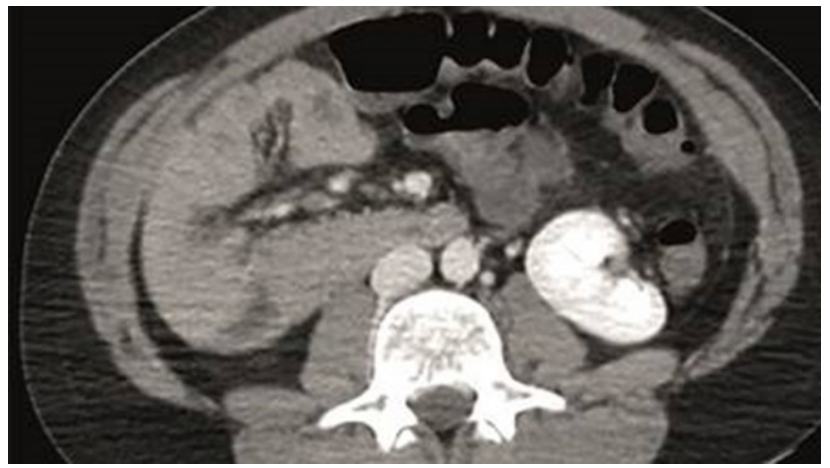

Figure 1. Axial contrast enhanced computed tomography, small bowel was on the right half of the abdomen and large bowel was on the left half of the abdomen.
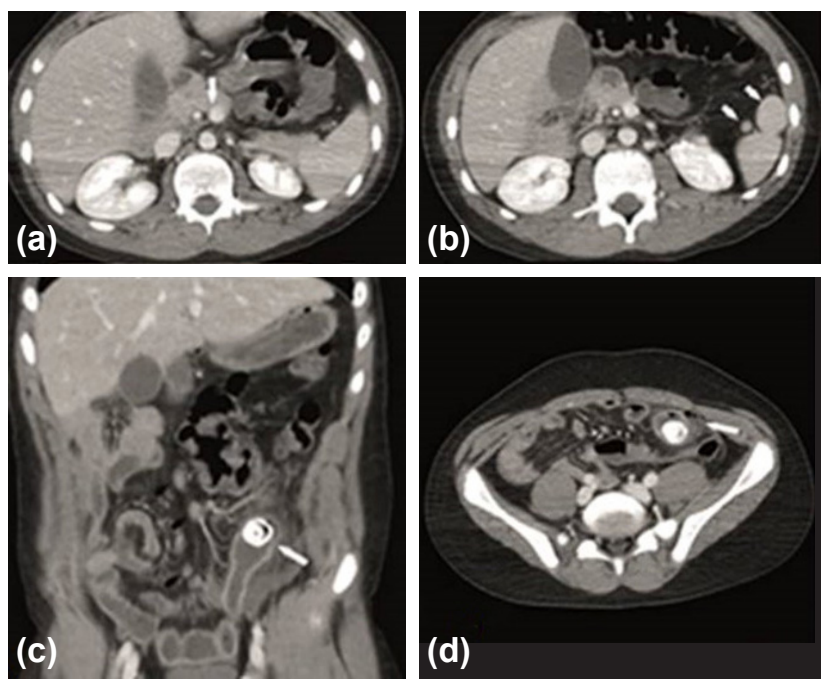

Figure 2. Contrast enhanced computed tomography. Superior mesenteric vein (white arrow) was on the left side of the superior mesenteric artery on axial CT image (a). Axial CT images showing polysplenia (white arrow) (b). Coronal reformatted CT images showing dilated appendix $(2 \mathrm{~cm}$ ) and $2 \mathrm{~cm}$ fecalith (white arrow) and a few enlarged lymph node in mesentery (black arrows) (c), Free air and focal mesenteric stranding were around the proximal part of appendix on axial CT image (white arrow) (d). surgery was performed. Surgical findings and pathology revealed perforated appendicitis. The patient had uneventful recovery and was discharged on the sixth postoperative day.

\section{DISCUSSION}

The incidence of MM is 1:200-500. ${ }^{[1]}$ These numbers may not reflect the truth of undetected asymptomatic cases. The nonrotation rate is relatively higher. In the intrauterine period, defects in the $2^{\text {nd }}$ and $3^{\text {rd }}$ stages of midgut rotation were caused by abnormalities such as malrotation and reverse rotation. When the intestinal loop does not enter the abdominal cavity again, because of exomphalos, nonrotation occurs. In the case of nonrotation, while the small intestines are observed on the right side and the large intestines are observed on the left side of the midline. ${ }^{[2]}$ Symptoms of MM are not well understood and it may remain asymptomatic. ${ }^{[3]}$ If malrotation is symptomatic, it usually occurs during the first months of life and is diagnosed within I year in $75 \%-85 \%$ of cases. ${ }^{[1]}$ MM should be considered important by surgeons, because the location of the appendix can be different. Another condition is the presence of volvulus and intestinal obstruction. Therefore, the surgeon should be informed about the embryology, malrotation, and anatomy of the intestinal rotation. ${ }^{[4]}$ Recently, the diagnosis of malrotation is increasing in asymptomatic patients. An urgent operation is necessary for patients with symptomatic MM, and treatment of asymptomatic incidental cases is still controversial. There is a lack of quality data to guide the management of these patients.

Midgut nonrotation is defined in the related extraintestinal anomalies. The related extraintestinal anomalies are leftsided SMV, polysplenia, short pancreas, absence of pancreatic uncinate process, SMA axis variation, prepancreatic portal vein and situs inversus are known to be associated with the extraintestinal anomalies. ${ }^{[5]}$ Polysplenia, left-sided SMV, and type la hepatic vein right portal vein variation were observed in our case. Renal malrotation was also observed, which was not before previously decsribed in literature.

In conclusion, because of the majority of cases with MM/ Nonrotation are asymptomatic, studies involving multicentre data are needed to better evaluate the profile of this patient group. ${ }^{[6]}$ In the differential diagnosis of left lower quadrant pain, there may be abnormal localized appendix problems; LSAA and nonrotation/MM anomalies related to LSAA should be considered. As a result, it is very important to be aware of the anatomical location of the intestines, due to errors the rotation of the midgut loop for surgeons and radiologists,

Conflict of interest: None declared.

\section{REFERENCES}

1. Soffers JH, Hikspoors JP, Mekonen HK, Koehler SE, Lamers WH. The growth pattern of the human intestine and its mesentery. BMC Dev Biol 2015;15:31. [CrossRef] 
2. Mohan P, Ramamoorthy M, Venkataraman J. Clinical vistas: nonrotation of the intestine. CMAJ 2008;179:49-50. [CrossRef]

3. Nehra D, Goldstein AM. Intestinal malrotation: varied clinical presentation from infancy through adulthood. Surgery 2011;149:386-93.

4. Appaji AC, Kulkarni R, Kadaba JS. Nonrotation of intestine: a case report. J Clin Diagn Res 2013;7:2575-6. [CrossRef]

5. Yang B, Chen WH, Zhang XF, Luo ZR. Adult midgut malrotation: mul- ti-detector computed tomography (MDCT) findings of 14 cases. Jpn J Radiol 2013;31:328-35. [CrossRef]

6. Graziano K, Islam S, Dasgupta R, Lopez ME, Austin M, Chen LE, et al. Asymptomatic malrotation: Diagnosis and surgical management: An American Pediatric Surgical Association outcomes and evidence based practice committee systematic review. J Pediatr Surg 2015;50:178390. [CrossRef]

\section{OLGU SUNUMU - ÖZET}

\section{İntestinal nonrotasyon ve sol alt kadranda perfore apandisit}

\section{Dr. Ertan Zengin, ${ }^{1}$ Dr. Arzu Turan, ${ }^{1}$ Dr. Ahmet Salih Calapoğlu, ${ }^{3}$ Dr. Ercan Nalbant, ${ }^{2}$ Dr. Gürkan Altuntaş ${ }^{2}$}

${ }^{1}$ Recep Tayyip Erdoğan Üniversitesi Tıp Fakültesi, Radyoloji Anabilim Dalı, Rize

${ }^{2}$ Recep Tayyip Erdoğan Üniversitesi Tıp Fakültesi, Acil Tıp Anabilim Dalı, Rize

${ }^{3}$ Recep Tayyip Erdoğan Üniversitesi Tıp Fakültesi, Çocuk Cerrahisi Anabilim Dalı, Rize

Akut apandisit, acil cerrahi gerektiren en yaygın akut karın ağrısı nedenlerinden biridir. Apendiksin varyasyonel anatomik lokalizasyonlarından dolayı olguların yaklaşık üçte birinde farklı bir kadranda ağrı olabilir. Akut apandisit, sitüs inversus totalis (SIT), Midgut malrotasyon (MM) gibi birkaç doğuştan anomali dışında sol alt kadran ağrısında nadiren akla gelir. Midgut malrotasyon nadir bir doğuştan anomali olup superior mezenterik damarların etrafında rotasyon veya bağırsakların fiksasyonu hatasından kaynaklanır ve bağırsağın inkomplet rotasyonu veya nonrotasyonu anlamına gelir. Burada sol alt kadran ağrısı ile başvuran ve akut perfore apandisit tanısı alan intestinal nonrotasyonlu bir olgu sunuldu. Klinisyenler intestinal nonrotasyonun sol alt kadran ağrısı ile prezente olan akut apandisit ile komplike olabileceğini bilmeli, sol alt kadran lokalizasyonlu apandisitlerde intestinal nonrotasyon akla gelmelidir.

Anahtar sözcükler: Akut apandisit; intestinal nonrotasyon; Midgut malotasyon; sol alt karın ağrısı.

Ulus Travma Acil Cerrahi Derg 2018:24(2):178-180 doi: 10.5505/tjtes.2017.58726 